\title{
Mali: FGC excisors persist despite entreaties
}

Frontiers in Reproductive Health

Follow this and additional works at: https://knowledgecommons.popcouncil.org/departments_sbsr-rh

Part of the International Public Health Commons, Public Health Education and Promotion Commons, and the Women's Health Commons

How does access to this work benefit you? Let us know!

\section{Recommended Citation}

"Mali: FGC excisors persist despite entreaties," FRONTIERS OR Summary. Washington, DC: Population Council, 2000. 


\section{Mali \\ Female Genital Cutting}

OR Summary 2

\section{FGC Excisors Persist Despite Entreaties}

\author{
Programs to persuade traditional practitioners to discontinue the practice of \\ Female Genital Cutting (FGC) are ineffective. Interventions must address \\ the demand for FGC rather than focusing on the supply.
}

\section{Background}

About 94 percent (DHS, 1996) of Malian women aged 15-49 have experienced Female Genital Cutting (FGC). In Mali FGC is associated with serious gynecological and obstetric complications.

In 1998 the National Center of Scientific and Technological Research of the Mali Ministry of Secondary and Higher Education and Scientific Research conducted an evaluation of programs to eradicate FGC. The study assessed the work of three national nongovernmental organizations

\section{Excisors continued to perform FGC. Most excisors remained unconvinced that FGC is harmful to women.}

(Association Malienne de Suivi et d'Orientation des Pratiques Traditionnelles/AMSOPT,

Association pour le Progrès et la Défense des Droits des Femmes/APDF, and Association de Soutien au Développement des Activités de Population/ASDAP) working in Bamako and five regions of Mali. These NGOs had attempted to persuade traditional practitioners of FGC

("excisors") to abandon the practice. Excisors are typically women from the blacksmith caste who come from families recognized by the community as excisors. Family members learn the practice by assisting excisors.
All three NGOs employed outreach workers to educate excisors and community members on the adverse effects of FGC on women's health. Two NGOs developed income generation schemes to provide the excisors with alternative revenues. One NGO sought to train excisors to advocate discontinuation of FGC. Researchers interviewed the heads of the three NGOs, 10 field staff, and 41 excisors. They also conducted 45 focus group discussions with 380 community members.

\section{Findings}

- Nearly all families practice FGC. Ninety-one percent of a nonrepresentative sample of 126 women under age 40 said that they had circumcised their daughters. Nevertheless, the practice may be declining, since 98 percent of the 134 women over age 40 said that they had circumcised their daughters.

- Major decision-makers regarding FGC are heads of family groups, religious leaders, the village chief, and grandmothers. Community members defended the practice as a means of continuing cultural traditions, fulfilling religious obligations, controlling female sexuality, and preparing girls for marriage.

- Community members and NGO staff reported that the excisors continued to perform FGC, despite their statements to interviewers that they 
had abandoned the practice. Excisors who had truly discontinued FGC did so for two major reasons: (1) retirement due to advanced age, poor eyesight, or replacement by their daughter; and (2) the promise of income from alternative activities. Most excisors remained unconvinced that FGC is harmful to women.

\section{FGC eradication programs must reach diverse audiences, including men, opinion leaders, religious leaders, and traditional midwives.}

- The strategy of converting excisors was ineffective because:

$\leftrightarrow$ Parents continued to seek out excisors as needed. They also found health workers willing to do FGC.

$\$$ The low social status of excisors does not put them in a decision-making role to end FGC.

$\nLeftarrow$ Excisors receive community recognition for their role and thus payments from their work are not their only source of motivation.

\section{Men Talk about FGC}

"The world changes. That's why we can now talk about excision with you. Before, no one would want to come to hear you discuss such topics."

"Perhaps our grandchildren will not go for excision. In any case, abandonment will not happen during our lifetime."

- Participants in a focus group discussion

\section{Policy Implications}

- Programs must focus on reducing demand for FGC from the community, rather than seeking to reduce the supply of excisors willing to do FGC.

- NGOs must develop broad-based community education campaigns that promote discussion about FGC and encourage local leaders to speak out against the practice. FGC eradication programs must reach diverse audiences, including men, opinion leaders, religious leaders, and traditional midwives.

- Research should focus on designing effective intervention strategies based on reproductive health and human rights, countering arguments made by FGC adherents, and documenting NGO activities. 